\title{
The implementation of students' campaign program to form Adiwiyata School in Malang, Indonesia
}

Krisnawati, Yuni

Muhammadiyah Metro Lampung University, Indonesia (krisnawatilampung@gmail.com)

Susilowati

Faculty of Mathematics and Science, State University of Malang, Indonesia (susilowatyum@gmail.com)

Irawati Al Muhdhar, Mimien Henie $\$

Faculty of Mathematics and Science, State University of Malang, Indonesia (mimienum@ @mail.com)

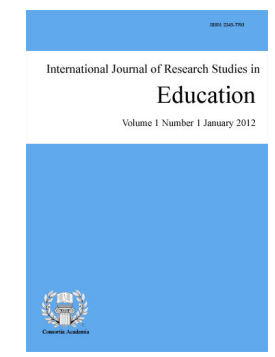

ISSN: 2243-7703 Online ISSN: 2243-7711

OPEN ACCESS

Rochman, Fathur

Faculty of Mathematics and Science, State University of Malang, Indonesia (rochmanum@gmail.com)

Budiasih, Endang

Faculty of Mathematics and Science, State University of Malang, Indonesia (budiasihum@ gmail.com)

\section{Abstract}

SMPN 2 Malang is a Non-Adiwiyata school which has never participated in Adiwiyata award. The administration of action research might mediate the school to participate in Adiwiyata award. This action research aimed at investigating the improvement of Adiwiyata program quality in SMPN 2 Malang through the students' campaign. The students' campaign program was carried out in 2 times, the first at break time and the second at flag ceremony moment so that the campaign could attract all of the school people's attention. The sampling method used was purposive sampling. The scoring technique used was non-test technique to the posters. The improvement of the quality of Adiwiyata school program was known from the observation and the interview. The data analysis was conducted based on the result of the observation and the interview. The Adiwiyata program quality enhanced in particular aspects, such as (1) waste-care HR capacity, (2) waste-care school rules, (3) waste-care learning syllabus development, (4) waste-care lesson plan development, (5) waste-care module, hand-out, and poster development, (6) waste-care action, (7) waste-care cooperation development, (8) trash can availability, and (9) cleaning tools availability.

Keywords: campaign program; problem based learning strategy (PBL); 6M based waste management module; Adiwiyata school; waste management 


\section{The implementation of students' campaign program to form Adiwiyata School in Malang, Indonesia}

\section{Introduction}

Humans' lives will always be related to their environment. It causes several problems since humans' needs rely heavily on the environment. The humans' activities in and needs from environment produce leftovers. Leftovers are also called as urban wastes or industry wastes (Miller, 2010). Wastes are resulted from economics system that produces cheap goods and enables the consumers to keep buying. Some states have already been managing wastes manually or modernly, yet compare to those, there are more states that have not even been able to manage the wastes. This is affected by several factors. According to Miller (2010) dumping wastes is a global problem which needs a number of costs and difficulties. The alternative problem solving can be done by changing the national development into environmental development or sustainable development for it consists of environmental education. School is a community where teachers, students, a principal, administrators, and staff gather and form an effective medium for learning and the people's awareness, in order to involve each individuals beginning from teachers, students, and staff to stop the environment damages due to human activities (KLH, 2005).

Environmental Education through formal education in primary and secondary schools is conducted regarding the effort to encourage the creation of knowledge and awareness of the school people in caring the nature. The government also states an Adiwiyata program on $21^{\text {st }}$ February 2006 to support and create environmental culture and care school that can participate in continuous care and development of the future generation (KLH, 2011). The purpose of the Adiwiyata program is to create responsible people in terms of protecting and managing the school environment. In order to achieve that purpose, there are 4 program components need to be done, namely a) environmental policy, b) environmental based curriculum, c) participative activities, and d) environmental facilities management.

Based on the observation result in SMPN 2 Malang in November 2013, it showed that: (1) there was environmental education and was an independent (monolithic) subject, yet it is omitted from the curriculum due to the lack of practical target. Besides, in the implementation of curriculum 2013, the government provides teachers' and students' manual book, (2) the students' behavior related to wastes management was considered low, for instance, there were students littering in classroom, in drawers, and in school environment. The students also bought food from school canteen rather than brought food from home, (3) since SMPN 2 Malang is a non-Adiwiyata school, the characteristics of Adiwiyata School does not appear. Several aspects in the Adiwiyata school program are: (a) the insufficient HR capacity, there is no school philosophy, vision, and mission related to waste care, also there is no waste care rules, (b) un-development of the school syllabus and lesson plans related to waste care learning, there is no module, handout, and posters related to waste care, and the development of waste care extracurricular, (c) create a waste care cooperation, (d) the development of the function of wastes management facilities: the availability of trash cans and cleaning tools.

The solving of the existence problems can be executed through: (1) integrating 6M based waste management module in natural science subject so that the environmental education materials can be taught even though the subject itself omitted. Nasution (2000) states that the utilization of module has several students advantages, they are: (a) it can enhance the students' activities and teachers' teaching activities maximally, (b) students can be more active during the learning process since they experience many problems to solve, (c) module can provide various and direct feedbacks so that the students' know their own learning outcome, (d) the students' efforts are guided because the module has clear purposes, (e) students can learn without depending on the teachers' quality, since the learning materials consisted in module. (2) In order to change the students' behavior, an action research implementing Problem Based Learning aided 6M based waste management module 
was conducted.

The culture of waste careless is a pitiful behavior and thus it needs problem solving. 6M concept was initiated by Al Muhdhar (1998) which consisted of several acts, namely reducing (mengurangi), reusing (menggunakan kembali), replacing (mengganti), separating (memisahkan), recycling (mendaur ulang), and composting (mengkompos). These are considered appropriate to solve the wastes careless behavior. Furthermore, based on the one of the learning strategies in curriculum 2013 and based on the students' learning interest outside the classroom and learning by doing, the implementation of Problem Based Learning (PBL) is expected to be able to help students to learn and improve the students' attitude and behavior related to wastes management. According to Poedjiadi (2005), contextual learning not only enables the knowledge construction but also helps to create affective, such as ethics development of the students, so that there will be intrinsic and permanent behavior changes.

Pannen et al. (2001) state that Problem Based Learning strategy has several advantages, they are it: (a) focuses on the meaning, rather than fact (deep versus surface learning), (b) improves the students' initiative, (c) develops the students' skill and knowledge, (d) develops group's interpersonal skill and dynamics, (e) in terms of the development of self-motivated behavior during the learning process, enables the students are able to do peer exploration under the guidance from the teacher so that the enjoyable learning can be achieved so that the students are motivated to learn, (f) builds relationship between the students and facilitator (instead of students and teacher). The result of the study through the implementation of Problem Based Learning (PBL) method by Sungur et al. (2006) state that the students who were taught by using PBL participate more actively for several motives like challenge, curiosity, and mastery compared to control students. Moreover, they seemed think that Biology is an interesting, important, and useful subject.

A study conducted by Park and Ertmer (2008) claim that the PBL participants illustrate the usage of technology is given more to the students after treatment compare to those from control group which experienced conventional method. The result of (Park \& Ertmer, 2008) study showed that PBL strategy improve the secondary school students' knowledge, attitude, and confidence. The implementation of Problem Based Learning strategy aided 6M based waste management module is effective when it is implemented in classroom, and socialized to all of the school people. The socialization is done to motivate the school people through students' campaign during the break time and after flag ceremony. The campaign program is a part of the materials in $6 \mathrm{M}$ based waste management module to persuade the school people to care the school environment and the quality of the school Adiwiyata program. The strength of the method is it can influence the behavior of the school people to care the environment, particularly wastes. This method can also be implemented easily by teachers especially in teaching environmental care material. Besides, the $6 \mathrm{M}$ based waste management theme is suitable to be implemented by either educated people or novice ones since the stages are easy.

\section{Method}

This study is a School Action Research (SAR) by implementing campaign program adopted from the 6M based waste management module parts of which materials have been taught in classroom. The present study was conducted in SMPN 2 Malang academic year 2013/2014. This study employed qualitative designed so the data was collected through observation and deep interview. The sampling technique used was purposive sampling technique. The subject of the study was the principal, teachers, students, administrator, school committee, and cleaning service.

The scoring technique used was non-test technique from the posters. The posters scoring were done based on the result, including the scoring of the students' ability in creating the products based on the use and the fixed criteria written on the observation sheet. While the observation and the deep interview was used to see the improvement of the quality of Adiwiyata school program at SMPN 2 Malang. The data were analyzed by using simple calculation where the obtained scores were converted from the quantitative data into qualitative data in 
Krisnawati, Y., Susilowati, Irawati Al Muhdhar, M. H., Rochman, F., \& Budiasih, E.

order to be able to describe. The instrument of the study was validated by three experts where creating posters was one of the activity inserted in the module that need to be done by the students. The result of the module validation from the experts was presented in Table 1.

\section{Table 1}

The Average of the Validation Results of the Students' Module from the Three Experts

\begin{tabular}{|c|c|c|c|c|c|c|}
\hline No. & $\begin{array}{l}\text { Validation } \\
\text { Aspects }\end{array}$ & $\begin{array}{l}\text { The Expert of } \\
\text { Environmental } \\
\text { Education } \\
\text { Material from } \\
\text { Adiwiyata } \\
\text { Assessor Team } \\
\text { KLH Batu (Ratna } \\
\text { Dwi UJ, SP) }\end{array}$ & $\begin{array}{l}\text { The Expert of } \\
\text { Module from } \\
\text { SuoM (Prof. Dr. } \\
\text { Punaji Setyosari, } \\
\text { M.Ed) }\end{array}$ & $\begin{array}{l}\text { The Expert of } \\
\text { Education } \\
\text { Practitioner from } \\
\text { Independent } \\
\text { Adiwiyata School } \\
\text { of SMAN } 8 \\
\text { Malang (Wiedia, } \\
\text { C.P., S.Pd) }\end{array}$ & $\begin{array}{l}\text { The Average } \\
\text { Score from } \\
\text { The Experts }\end{array}$ & $\begin{array}{l}\text { The } \\
\text { Average } \\
\text { Score of } \\
\text { the Overall } \\
\text { Aspects }\end{array}$ \\
\hline 1. & Content & 4,8 & 4,4 & 4,2 & $\begin{array}{l}4,5 \\
\text { Categorized } \\
\text { as good, } \\
\text { tend to be } \\
\text { very good }\end{array}$ & \multirow{2}{*}{$\begin{array}{l}4,4 \\
\text { Categorize } \\
\text { d as good, } \\
\text { tend to be } \\
\text { very good }\end{array}$} \\
\hline 2. & Sistematika & --- & 4,4 & 4,2 & $\begin{array}{l}4,3 \\
\text { Categorized } \\
\text { as good, } \\
\text { tend to be } \\
\text { very good }\end{array}$ & \\
\hline
\end{tabular}

Note. Maximum score $=5$

\section{Findings}

The data analysis from the observation and the interview, are presented in Table 1 and 2. Poster is one of indicators in the cognitive scoring, in the aspect of create (C6). The posters are campaign by their own makers. The average score of posters achieved by class VII A was 90.1; class VII B was 90.6; class VII C was 94.4; while class VII J was 95.6. The average score of these four classes was 92.7. The average posters'scores for each class is showed in Table 2.

Table 2

The Average Score of Posters from Each Class

\begin{tabular}{|c|c|c|c|c|c|c|c|c|c|}
\hline \multirow{2}{*}{ No. } & \multirow{2}{*}{$\begin{array}{l}\text { Scoring } \\
\text { aspects }\end{array}$} & \multirow{2}{*}{ Descriptor } & \multirow{2}{*}{$\begin{array}{l}\text { Max. } \\
\text { score }\end{array}$} & \multicolumn{4}{|c|}{ Class } & \multirow{2}{*}{ Mean } & \multirow{2}{*}{$\begin{array}{c}\text { Mean/ } \\
\text { indicator }\end{array}$} \\
\hline & & & & VII A & VII B & VII I & VII J & & \\
\hline \multirow{3}{*}{1.} & Language & Openness & 10 & 7.6 & 8.0 & 8.0 & 7.9 & 7.9 & \multirow{3}{*}{7.9} \\
\hline & & Communicative & 10 & 7.8 & 8.0 & 8.1 & 7.9 & 7.9 & \\
\hline & & Interesting & 10 & 7.5 & 7.6 & 8.3 & 8.5 & 7.9 & \\
\hline \multirow[t]{2}{*}{2.} & Writing & Readability & 10 & 7.8 & 7.8 & 8.1 & 8.0 & 7.9 & \multirow{2}{*}{7.8} \\
\hline & & Attractiveness & 10 & 7.5 & 7.5 & 8.0 & 8.1 & 7.8 & \\
\hline \multirow{2}{*}{3.} & Picture & Attractiveness & 10 & 7.5 & 7.8 & 8.2 & 8.8 & 8.1 & \multirow{2}{*}{8.1} \\
\hline & & Communicativeness & 10 & 7.8 & 7.5 & 8.3 & 8.4 & 8.0 & \\
\hline 4. & Color & Attractiveness & 10 & 7.5 & 7.7 & 8.1 & 8.8 & 8.1 & 8.1 \\
\hline \multirow{3}{*}{5.} & & Effectiveness & 10 & 7.7 & 7.7 & 8.1 & 7.9 & 7.8 & \multirow{3}{*}{8.0} \\
\hline & Message & communicativeness & 10 & 7.5 & 7.7 & 8.0 & 7.9 & 7.8 & \\
\hline & & Meaningful & 10 & 8.6 & 8.3 & 8.3 & 8.6 & 8.5 & \\
\hline 6. & Punctuation & Punctuation & 5 & 5.0 & 5.0 & 5.0 & 5.0 & 5.0 & 5.0 \\
\hline \multicolumn{2}{|c|}{ Average } & & & 90.1 & 90.6 & 94.4 & 95.6 & 92.7 & \\
\hline
\end{tabular}

Based on Table 3 covering Adiwiyata school program measurement in SMPN 2 Malang, it was obtained that the increasing score from bad to good occured on the development of waste care participative based activities 
The implementation of students' campaign program to form Adiwiyata School in Malang, Indonesia

that is creating waste care cooperation, while the increasing score from moderate to good occured on the development of: (1) school policy, covering increasing waste care HR capacity and waste care school rules; (2) waste care curriculum that is the development of waste care module, hand out, and posters; (3) waste care participative based activities by doing waste care commotion; (4) the function of the wastes management tools quality that is the availability of trash can cleaning tools. The increasing score from moderate to very good occured on (a) the development of waste care curriculum covering the development of waste care syllabus and lesson plan as well as extracurricular.

Table 3

Adiwiyata School Program Measurement Before and After Treatment

\begin{tabular}{|c|c|c|c|}
\hline No & Measurement Aspects & $\begin{array}{c}\text { Before } \\
\text { treatment }\end{array}$ & $\begin{array}{c}\text { After } \\
\text { treatment }\end{array}$ \\
\hline \multirow{4}{*}{1} & Development of School Policy: & & \\
\hline & - Increasing waste care HR capacity & 3 & 4 \\
\hline & - Waste Care based School Philosophy, Vision, Mission & 3 & 3 \\
\hline & - Waste Care School Rule & 3 & 4 \\
\hline \multirow{6}{*}{2} & Development of Waste Care Curriculum: & & \\
\hline & - Development of waste care syllabus & 3 & 5 \\
\hline & - Development of waste care lesson plans & 3 & 5 \\
\hline & - Development of waste care module, handout, and posters & 3 & 4 \\
\hline & - Development of waste care learning method and nature material & 4 & 4 \\
\hline & - Development of waste care extracurricular & 4 & 5 \\
\hline \multirow{4}{*}{3} & Development of Waste Care Participative based Activities: & & \\
\hline & - Administering waste care extracurricular & 4 & 4 \\
\hline & - Administering waste care commotion & 3 & 4 \\
\hline & - Creating waste care cooperation & 2 & 4 \\
\hline \multirow{7}{*}{4} & a. Development of the function of the wastes management tools: & & \\
\hline & - Trash can availability & 3 & 4 \\
\hline & - Cleaning tools availability & 3 & 4 \\
\hline & - Cleaning tools variety availability & 4 & 4 \\
\hline & - Temporary wastes collector availability & 4 & 4 \\
\hline & b. Development of waste management system & & \\
\hline & - Waste management way & 3 & 3 \\
\hline$\Sigma$ & & 49 & 65 \\
\hline
\end{tabular}

\section{Table 4}

The Measurement of t-test value of Adiwiyata School Program Before and After Treatment

\begin{tabular}{cccccccc}
\hline Pair 1 & $N$ & $M S$ & $S E$ & $S D$ & $t$ & df & Sig.(2-tailed) \\
\cline { 2 - 7 } Before-after student campaign program & 16 & -0.81250 & 0.75000 & 0.18750 & -4.333 & 15 & 0.001 \\
\hline
\end{tabular}

Table 4 shows that the $\mathrm{p}$-value for the 2-tailed test $=0.001$. Since the hypothesis test is one-tailed, thus the $p$-value is divided into 0.0005 . The p-value $(0.0005)<\alpha=0.05$, it reveals that the Ho cannot be accepted: $\mu 1 \geq \mu 2$ or $\mu 1 \geq 0$ (there is no significance difference between before and after the implementation of students' campaign program towards the improvement of Adiwiyata school program).

\section{Discussion}

This research is an action research aimed at improving the quality of Adiwiyata school program in SMPN 2 Malang through the students' campaign program. As it is stated before that SMPN 2 Malang is a non-Adiwiyata school which needs help to participate in a nature conservation through formal education. This is important since wastes management and natural conservation cannot only be done through technical approach but also through moral and ethics education in a formal education. As it is stated by Rathi (2007) that Land is extremely scarce 
and expensive in a metropolitan city like Mumbai. Moreover, the cost of land varies significantly from ward to ward. Hence, it will be of interest to see the change in waste management strategy with the change in cost of land. It is revealed that the waste landfill in Mumbai, India decreases day by day. This fact is not only occured in Mumbai but also in other countries included Indonesia.

The proper waste management is directed to literate people, thus secondary school students are expected to contribute in reducing the volume and types of wastes. The variety of wastes is defined by Hřebíček and Soukopová (2010) the municipal solid waste is all waste generated within the community (cities and villages) by the activities of its inhabitants (households) and businesses (e.g. trade waste), which is separated into its components and transported to waste treatment facilities where is recovered or disposed. The MSW normally contains the remains of food and vegetables, paper, plastic, glass and metal containers, printed matter (newspapers, magazines, and books), destroyed products, ashes and rubbish, used or unwanted consumer goods, including shoes and clothing.

Other than that, the impacts of wastes are also varied as explained by EPA (2009) people who frequently visit or rummage through open dumps can be hurt by sharp objects. They also can come in contact with toxic materials or contagious pathogens, which can lead to gastroenteritis; skin rashes and infections; or eye, nose, and ear infections. Open dumps also attract pests such as insects, rats, bears, birds, and raccoons that can potentially hurt people and spread disease. Based on the before-mentioned citation, it can be concluded that the proper and quick wastes management should be done daily. Ilaboyaa et al. (2011) On a local or community level, integrated solid waste management programs essentially consist of the following five steps: 1 . Waste source identification and characterization; 2. Efficient waste landfill; 3. Reduction of volume and toxicity of the waste to be discarded; 4 . Land disposal or incineration of the waste; 5. Optimization of the first four steps to reduce cost and environmental impact

In relation to the omission of environment education subject in the curriculum of SMPN 2 Malang, this action research implemented Problem Based Learning (PBL) strategy aided 6M waste management module. The purpose of the implementation of $6 \mathrm{M}$ module is to integrate the environmental education materials contained in the module to natural science subject, while the implementation of PBL strategy aimed at making the presentation of the materials be more attractive and the students can learn the environmet directly. According to (Siskandar, 2006; Rosyadi \& Amin, 2009) the Citizenship and Natural Environment program, particularly in formal education, can be delivered through two approaches, namely monolithic approach and integrative approach. The monolithic approach is an approach based on a thought that every subjects is an independent component in a curriculum and has a particular purpose, while integrative approach is an approach based on a thought that a subject should be integrated to other subjects.

Based on the definition, it is necessary to integrate the environmental education materials to natural sciences subject. The effectiveness of the learning through Problem Based Learning (PBL) aided 6M based waste management module is supported by several studies. Based on Sudarna's (2006) study, it was revealed that the implementation of problem based learningstrategy can improve the students' ability in solving problems, improving the quality of learning process based on the students' activities, and improving the students' learning outcome. Another study conducted by Purnomo (2009) resulted that the implementation of PBL aided module to metrology lecture improve the students' activities and independency, as well as improve the quality of the lecture itself and the students learning achievement.

According to Cuccurullo et al. (2013) type of knowledge are procedural knowledge, impact knowledge and normaative knowledge. The transmission of procedural knowledge, e.g knowledge about where, when, and how recycling. Impact knowledge, which refers to indivual beliefs about the advantages of recycling in terms of reduction of pollution and energy saving. A third type of knowledge is the normative knowledge, i.e. the knowledge about the behaviours of others. The learning result through the implementation of Problem Based Learning (PBL) aided 6M waste management module is poster. The poster creation aimed at investigating the 
students' creativity and emphaty towards environment. One's creativity, such as problem solving, is a kind of transfer act since it involve the application of knowledge and skill in a new condition. According to Ormrod (2009) Creativity is not merely independent entity that can be trained through simple excercises. Yet, creativity has different form in different content, and students tend to be more creative at certain aspect. In terms of poster creation, it can be seen that not all groups can describe what are on their mind though they want to; this is caused by their creativity. Posters are also expected to be able to represent one's emphaty through the posters campaign and attract emphaty from others who see it.

The posters are used as the students' campaign media. The theme of the posters is related to $6 \mathrm{M}$ activities (reduce, reuse, replace,separate, recycle, and compost) which are considered ways of waste management. The activities of 6M have similar way in managing wastes with that suggested by Mwanza and Phiri (2013) proper waste management is needed to reduce health problems, water pollution risks and other environmental hazards, besides the negative aesthetic impacts. Integrated Solid Waste Management (ISWM) is a comprehensive waste prevention, recycling, composting, and disposal program. The model of wastes management is a model of waste management implemented in Buwaluyo, where some of the ways are taught in environmental education subject in SMPN 2 Malang. After the students learn 6M materials, they have to campaign the posters they made related to $6 \mathrm{M}$ action.

Rathi (2007) states that community participation in waste management has been initiated in Mumbai as a result of good urban governance campaign, which started as a joint project between the Government of India and the MCGM in collaboration with United Nations Centre for Human Settlements. (Decety \& Jackson, 2004; White, 2014) states that in literature social cognitive neuroscience, brain activity is closely related to four empathy components: affective sharing, consciousness, perspective taking, and emotional adjustment. They call it "Empathy relatied Responding" Leitz et al. (2011) that is a relationship between empathy and pro social behavior. EAI includes empathy as a component that can improve a decision taking. This is an important point for the sake of social action campaign. However, researchers infered that empathy has the lowest correlation with other components. Empathy is a representation of changing and behavior commitment.

Based on the above mentioned theory, it can be seen that the campaign program of the students of SMPN 2 Malang can support the Adiwiyata school program. The score of the Adiwiyata school program of SMPN 2 Malang after the implementation of the students' campaign program is higher than that of before the implementation of the students' campaign program. The result of the t-test shows that the p-value $(0.0005)<a$ $=0.05$, hence Ho cannot be accepted: $\mu 1 \geq \mu 2$ or $\mu 1 \geq 0$ (there is no significant difference between before and after the implementation of students' campaign program towards the improvement of Adiwiyata school program). Based on the analysis, it can be concluded that there is a significant difference of the improvement of Adiwiyata school program at SMPN 2 Malang between before and after the implementation of students' campaign program. The measuring aspects of the Adiwiyata school program in SMPN 2 Malang improve as follow:

The development of school policy include: a) the improvement of waste care HR capacity. The improvement is supported by the commitment of a teacher, named Zunif Setyorini teaching natural science in class VII, to integrate the syllabus, lesson plans completed with environmental based materials, and $6 \mathrm{M}$ waste management module for the students of SMPN 2 Malang for the next academic year. She relates the conceptual and procedural knowledge in solving environmental problems and the implementation in daily activities, as well as provides examples for the students to take a good care of the environment by separating wet wastes and dry wastes as well as practicing takakura composting at home. The teacher's knowledge related to $6 \mathrm{M}$ action to the students.

Cuccurullo et al. (2013) claims that knowledge is often assessed by asking to identify the recyclable materials and evaluating the percentage of waste correctly classified. This good behavior of the natural science teacher in line with Rathi's (2007) statement that all residents who fall under the Advanced Locality Management (ALM) scheme have to segregate their waste into biodegradable and recyclable material. The aim 
Krisnawati, Y., Susilowati, Irawati Al Muhdhar, M. H., Rochman, F., \& Budiasih, E.

of separating wastes is to distinct the wet wastes from the counterpart. Wet wastes can easily be decayed so it can be composted, while the dry wastes are the contrary, thus they can only be recycled. Moreover, Rathi (2007) said that rag pickers organized and trained by NGOs collect these wastes and sort them out further. They process biodegradable waste and sell the recyclable material. Wet wastes from the teacher's house were used as the material for takakura composting. Zenk et al. (2010) state that composting is a viable technology to treat the organic fraction of Municipal Solid Waste (MSW) because it stabilizes biodegradable organic matter and contributes to reduce the quantity of MSW to be incinerated or landfilled.

Partanen et al. (2010) claim that composting is an aerobic microbiological process that is facilitated by bacteria and fungi. Composting is also a method to produce fertilizer or soil conditioner. This means that composting brings more advantages in wastes management compared to burning, reducing volume of wastes, reducing the illness factor, vanishing smell, and saving the waste landfill. The students of SMPN 2 Malang are taught to do takakura composting. The materials consist of grass, vegetable wastes, and dry leaves at school. These materials are similar with that stated by Zenk et al. (2010) all of the materials that may be composted (e.g., leaves, brush, grass, food waste, newspaper) originally are produced by trees or other plants.

The students were asked to create goods related to the conservation of environment, prevention of environment pollution and damage. The products of the students were in form of practicum reports, posters, compost fertilizer, and recycled goods. According EPA (2011) burning waste can release dangerous chemicals into the atmosphere where they are inhaled immediately or settle on plants and bodies of water. Once the chemicals are released into the atmosphere they may enter the food chain. Air pollutants released by backyard burning include dioxins, fine particulate matter, carbon monoxide, nitrogen oxides, polycyclic aromatic hydrocarbons, volatile organic compounds, and hydrogen chloride. The ash residue from burning also can contain dangerous levels of toxic heavy metals, such as mercury, lead, chromium, and arsenic, which can contaminate water or enter the food chain. This becomes a base of recycling activity, which brings positive impact to living things and the environment, if it is seen from the food chain impact. The recycling activity can also keep the environmental health, as it is stated in EPA (2009) we can turn items that would be waste into valuable resources by recycling materials like glass, metal, plastics, and paper. Recycling facilities can process them into new materials and products. The students' products in form of posters, recycled products, and compost are presented on Figure 1 and 2.
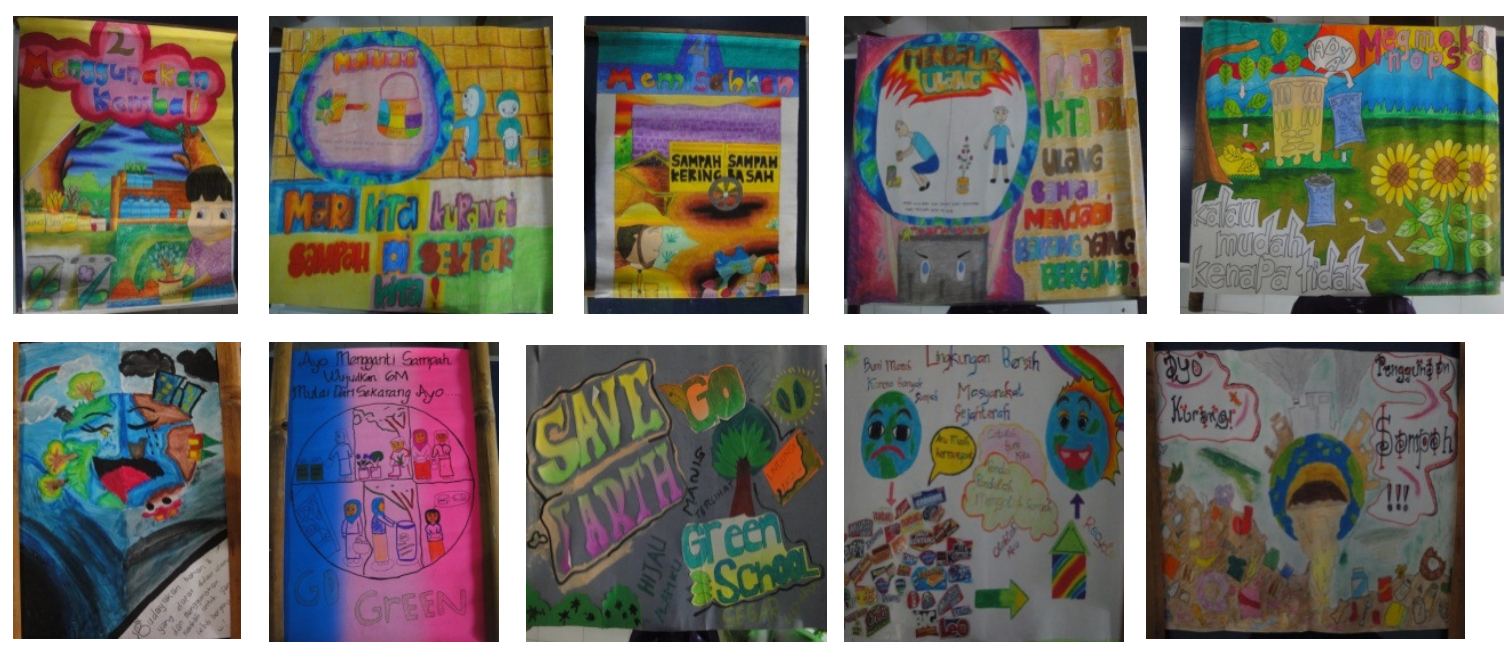

Figure 1. Some of the students' posters 


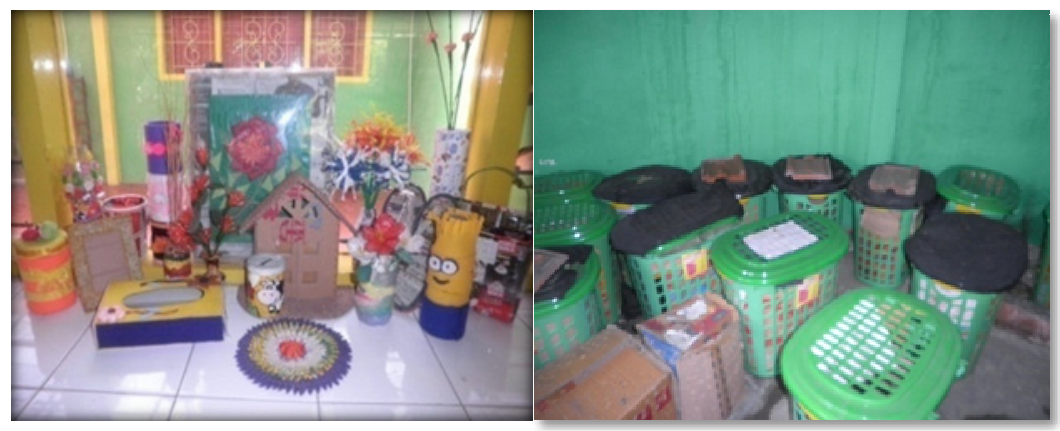

(a)

(b)

Figure 2. (a) some of the students' recycled goods, (b) Takakura Compost

The students implemented the knowledge obtained from the learning to solve the environmental problems in daily life. It can be seen from the students' awareness and attitude of waste management in school. The students practice the "reduce and replace" activities by brought food from home so that they did not need to bought food in canteen.

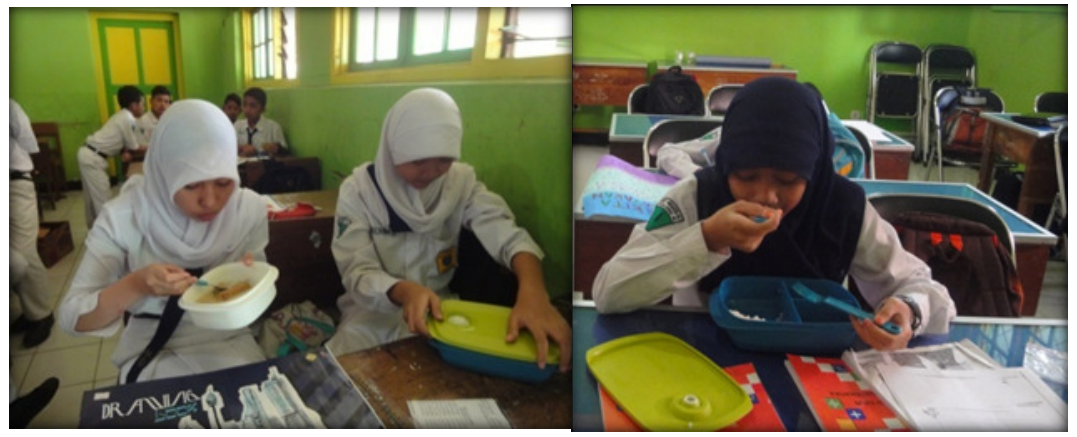

Figure 3. Some students prefer bring food from home

Furthermore, the forming of steering committee for environmental care school program, which is known as Adiwiyata School Team and the planning of Adiwiyata Program in form of environmntal analysis, verified Rathi's (2007) statement that it can be inferred from the literature that no one method in isolation can solve the problem of waste management. There is a need to combine different methods and stakeholders in such a way so as to minimize environmental and social costs associated with waste management. The significance of this study is not only for the Adiwiyata School Team but also the principal as the highest governance of the school. Thus, the principal should be able to control the improvement of the school progress. (b) The waste care school rule. The rules was set as the "environment police" thus each students who disobey the rules, like littering, will get penalty.

The development of waste care curriculum include: (a) the development of waste care syllabus and lesson plans. The developed syllabus and lesson plans implemented approaches, strategies, methods, and teaching techniques that involve the students to be active during the lesson. The method used is discussion, task (creating recycled products, composting, and making posters), observation, exploration, practicum, and campaign. The lesson plans were created completely, both for in class and outclass activities. The development of learning indicators and scoring instruments for the environmental education includes the measurement of knowledge, attitude, and behavior changes.

The development of the local material include the problems of types and impact of wastes, as well as how to 
Krisnawati, Y., Susilowati, Irawati Al Muhdhar, M. H., Rochman, F., \& Budiasih, E.

reduce wastes through $6 \mathrm{M}$ activities (reduce, reuse, replace, separate, recycle, and compost). (b) the development of waste care module, handout, and posters. The development of module was done by applying $6 \mathrm{M}$ based waste management module written by Prof. Dr. Hj. Mimien Henie Irawati Al Muhdhar, M.S., et al. while the development of posters were done by assigning students, so that the students can build their own good characters, besides, scout value also implement religious, nationalism and patriotism, disciplinary, responsibility, care, and honesty values. (c) The development of waste care curricular is showed by the existence of water purifying activity in scout and organic plants reforestation in art subjects.

The development of waste care participative based activities includes (a) conducting waste care activities. These waste care activities were done by conserving and taking care school buildings and environment by school people. It can be seen from the dividing cleaning activities of each class every day, Saturday clean activity, and $6 \mathrm{M}$ based waste management campaign. The campaign was done in break time and at flag ceremony on each Monday. This is done to ask all the school people can attend and apply the action to save environment. Besides, it is necessary to use the school land and facilities based on protection and environmental management aspects, such as building additional park, fish pond, and wastes management (in form of takakura composting facility).
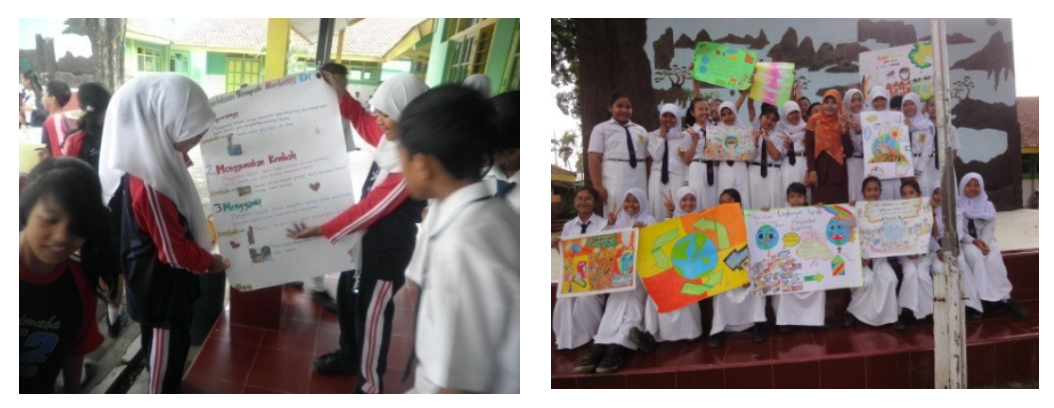

(a) (b)

Figure 4. (a) The students' campaing in break time, (b) after campaign acivity
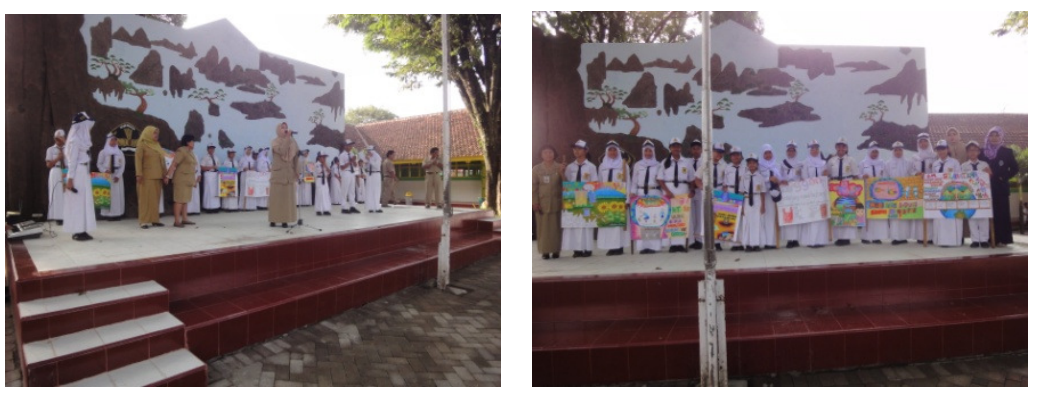

(a) (b)

Figure 5. (a) The teachers and students prepare the campaign at flag ceremony, (b) After campaign at flag ceremony

The development of waste care cooperation. The development of waste care can be done through creating a good relationship with waste Bank. The students were guided to collect plastic wastes to be sold to waste bank, which then earn money monthly or every six months. According to Ohri and Singh (2010), the financial aspect considered factors for reducing the direct economic burden on the municipal authorities by option of tariff from households, comercial places, academic institutions and other waste generators. Through the cooperation with waste bank, SMPN 2 Malang should pay for waste retribution monthly, yet it also brought an advantage such as saving from the result of waste selling to waste bank. 
The implementation of students' campaign program to form Adiwiyata School in Malang, Indonesia

The development the function of the quality of waste management facilities include: (a) the availability of trash can and cleaning tools. The trash can availability in 30 classes before and after the implementation of the treatment changed; at the first time, each classes only possessed one trash can, after the treatment, there are two trash cans to separate wet wastes from dry wastes. The cleaning tools availability in each classes such as brooms, mops, dusters, and trash cans are more complete.

Those improvements are much left behind compared to that possessed by SMAN 8 Malang, which has become independent Adiwiyata school, in contrast, SMPN 2 Malang does not an Adiwiyata school. Landriany (2014) describes the school vision and mission of SMAN 8 Malang, that is Creating Bright Person who possesses Good Behavior and Respect Nature, the School expects that the students do not only intellectually clever, but also smart and have a good behavior, and also care to the surrounded environment, either social environment or natural environment. One prerequisite to become an independent Adiwiyata school is SMAN 8 Malang have to have 10 induced schools, thus SMAN 8 Malang should induces the ten schools to be able to join the selection of Adiwiyata school, respectfully from the level of city, province, and national. In a participative activity, SMAN 8 Malang builds a relationship with several institution, viz. Pertamina, PLN, Public and Private Campuses, health Department, Infocom Department, Board of Natural Environment, Board of Family Planning of Citizen Empowerment, Waste Bank, Resort Police and Sector Police of Lowokwaru, RT, RW, subdistrict of Sumbersari, district of Lowokwaru, alumni, students' parents, committee, and Independent Board of Citizen, namely P-WEC and Benih Bunga Matahari.

Based on the above description, it can be seen that the vision and mission of SMAN 8 Malang are clear and direct to environmental based schools, while the program in SMPN 2 Malang has not been achieved yet. In addition, SMAN 8 Malang builds a good relationship with several institutions since it can prove itself as an independent Adiwiyata school so many institutions are willing to help. This can be suggested to SMPN 2 Malang which is arranging its fund well by dividing the need of development of education and environment. The awareness of people of SMPN 2 Malang to keep the environment is still low so that campaign becomes a priority need to be done. Through the students' campaign, the students of SMPN 2 Malang start participating in a Adiwiyata school selection in the level of city. Thus, it can be assumed that even a simple thing like the students' campaign can encourage the school people's empathy to support the school development better.

\section{Conclusions and Suggestions}

\subsection{Conclusions}

Based on the discussion above, it revealed that the students' campaign program can improve the Aiwiyata school program in SMPN 2 Malang in terms of: 1) The development of school policy covering: increasing waste care HR capacity, namely committed teachers to teach environmental education and forming the steering committee of environmental caring school or Adiwiyata school team, 2) The development of waste care curriculuminclude (a) the development of waste care syllabus and lesson plans with approaches, strategies, methods, and teaching techniques that involve the students to be active during the lesson.(b) the development of waste care module, handout, and posters. The development of module was done by applying 6M based waste management module written by Prof. Dr. Hj. Mimien Henie Irawati Al Muhdhar, M.S., et al. while the development of posters were done by assigning students in groups in each class to campaign their posters. (c) The development of waste care curricular is showed by the existence of water purifying, 3) The development of waste care participative based activities include (a) conducting waste care activities were done by conserving and taking care school buildings and environment by school people. It can be seen from the dividing cleaning activities of each classes every day, Saturday clean activity, and 6M based waste management campaign, (b) The development of waste care cooperation can be done through creating a good relationship with waste Bank.4) The development the function of the quality of waste management facilities include: (a) The trash can availability in 30 classes before and after the implementation of the treatment changed; at the first time, each classes only 
Krisnawati, Y., Susilowati, Irawati Al Muhdhar, M. H., Rochman, F., \& Budiasih, E.

possessed one trash can, after the treatment, there are two trash cans to separate wet wastes from dry wastes. Other than that, the practical implication and the contribution from this study are: a) for the researcher, it can be used as a base to conduct future studies using various innovative methods that can be implemented in other schools., b) the module used in this study might provide detail operational information related to the model of $6 \mathrm{M}$ based waste management learning for the module of teachers and students were arranged based on the criteria of good module development, so that it enable the teachers and students to carry out the waste management learning theoretically and practically, c) for teachers, it can be used as the alternative method in teaching and learning process, d) it can improve the behavior of the teachers and the students in managing waste, e) it supports the government to succeed the Adiwiyata school program indirectly.

\subsection{Suggestions}

Based on the study, it can be concluded that: 1) In order to achieve the Adiwiyata school, each school might take some times and through steps, high commitment, consistency and cooperation, aswell as support from all of the school people. 2) even though it takes time, the usage of plastics wrap for food in canteen, are changed into more recyclable wrap, or students suggested to bring their own lunch boxes when they buy food and drink. In order to improve the quality of health canteen and good environment, school can also invite a health officer, 3 ) introduce the $6 \mathrm{M}$ activities as well as environmental care behavior in the Students Orientation Activity in every new academic year.

NOTE: Figures 1, 2, 3, 4 and 5 in this study were documented after being permitted by the students of class IIa, IIb, IIi and IIj of SMPN 2 Malang

\section{References}

Al Muhdhar, M. H. I. (1998). The linkage between social factors, economic factors, cultural factors, knowledge, and attitude of the mother - housewife in the management of household waste, the behavioral manifestations of housewives in the management of household waste [Keterkaitan antara faktor sosial, faktor ekonomi, faktor budaya, pengetahuan, dan sikap ibu-ibu rumah tangga dalam pengelolaan sampah rumah tangga, dengan manifestasi perilaku ibu- ibu rumah tangga dalam pengelolaan sampah rumah tangga]. Unpublished doctoral dissertation, State University of Malang, Indonesia.

Cuccurullo, S., Francese, R., Passero, I., \& Tortora, G. (2013). A 3D serious city building game on waste disposal. International Journal of Distance Education Technologies, 11(4), 112-135. http://dx.doi.org/10.4018/ijdet.2013100108

United States Environmental Protection Agency (EPA). (2009). What is an integrated waste management plant? Retrieved from http://www.epa.gov/osw/wyl/tribal/pdftxt/twj-7.pdf

Hřebíček, J., Hejč, M., \& Soukopová, J. (2010). Integrated model of municipal waste management of the Czech Republic. Paper presented at the International Congress on Environmental Modelling and Software Modelling for Environment's Sake, Fifth Biennial Meeting, Ottawa, Canada.

Ilaboya, I. R., Atikpo, E., Asekhame, F. F., Onaiwu, D. O., \& Omofuma, F. E. (2011). Design of an integrated solid waste management scheme: a model design for Igbinedion University community. Journal of Applied Technology in Environmental Sanitation, 1(2), 125-138.

Kementerian Negara Lingkungan Hidup. (2011). Adiwiyata guide [Panduan Adiwiyata]. Jakarta: KNLH.

Kementrian Lingkungan Hidup Republik Indonesia. (2005). Environmental education [Pendidikan lingkungan hidup]. Retrieved from http://www.menlh.go.id/pendidikan lingkungan hidup/

Landriany, E. (2014). Adiwiyata policy implementation in an effort to realize the high school environmental education in Malang [Implementasi kebijakan Adiwiyata dalam upaya mewujudkan pendidikan lingkungan hidup di SMA Kota Malang]. Jurnal Kebijakan dan Pengembangan Pendidikan, 2(1), 82-88. 
The implementation of students' campaign program to form Adiwiyata School in Malang, Indonesia

Lietz, C. A., Gerdes, K. E., Sun, F., Mullins G. J., Wagaman, M. A., \& Segal, E. A. (2011). The empathy assessment index (EAI). Journal of the Society for Social Work and Research, 2(2), 104-124. http://dx.doi.org/10.5243/jsswr.2011.6

Miller, D. A. (2010). Garbage and recycling. United State of America: Gale, Cengage Learning.

Mwanza, B., \& Phiri, A. (2013). Design of a waste management model using integrated solid waste management: A case of Bulawayo City Council. International Journal of Water Resources and Environmental Engineering, 5(2), 111-118.

Nasution, S. (2000). Various approaches to teaching and learning [Berbagai pendekatan dalam proses belajar \& mengajar]. Jakarta: Bumi Aksara.

Ohri, A., \& Singh, P. K. (2010). Development of decision support system for municipal solid waste management in India: A review. International Journal of Environmental Sciences, 1(4), 440-453.

Ormrod, J. E. (2008/2009). Educational psychology helps students grow and thrive (vol. 2, 6th ed.) [Psikologi pendidikan membantu siswa tumbuh dan berkembang]. Translated by W. Indianti, E. Septiana, A. Y. Saleh, \& P. Lestari. Jakarta: Erlangga.

Pannen, P., Dina, M., \& Mestika, S. (2001). Constructivism in learning [Konstruktivisme dalam pembelajaran]. Jakarta: Diknas.

Park, S. H., \& Ertmer, P. A. (2007). Impact of problem-based learning (PBL) on teachers' beliefs regarding technology USA. Journal of Research on Technology in Education, 40(2), 247-267. http://dx.doi.org/10.1080/15391523.2007.10782507

Partanen, P., Hultman, J., Paulin, L., Auvinen, P., \& Romantschuk, M. (2010). BMC microbiology: Bacterial diversity at different stages of the composting Process. Retrieved from http://www.biomedcentral.com/1471-2180/10/94

Poedjiadi, A. (2005). Science society technology [Sains teknologi masyarakat]. Bandung: PT. Remaja.

Purnomo, E. (2009). Implementation of problem based learning ( PBL ) module aided in improving the quality of lectures metrology [Implementasi problem based lerning (PBL) berbantuan modul dalam upaya meningkatkan kualitas perkuliahan metrology]. Yogyakarta: Fakultas Teknik Universitas Negeri Yogyakarta.

Rathi, S. (2007). Optimization model for integrated municipal solid waste management in Mumbai, India. Environment and Development Economics, 12, 105-121. http://dx.doi.org/10.1017/S1355770X0600341X

Rosyadi, H., \& Amin, D. (2009). Integration of Population and Environment Education ( PKLH ) in social studies in junior high [Integrasi Pendidikan Kependudukan dan Lingkungan Hidup (PKLH) pada mata pelajaran IPS di SMP]. Region, 1(3), 1-11.

Suardana, I. N. (2006). Application of problem-based learning strategy with module -assisted cooperative approach to improve the quality of student learning processes and outcomes in physical chemistry lecture I [Penerapan strategi pembelajaran berbasis masalah dengan pendekatan kooperatif berbantuan modul untuk meningkatkan kualitas proses dan hasil belajar mahasiswa pada perkuliahan kimia fisika I]. Jurnal Pendidikan dan Pengajaran IKIP Negeri Singaraja, 39(4), 751-768.

Sungur, S., \& Tekkaya, C. (2006). Effects of problem-based learning. The Journal of Education Research, 40(4), 155-160.

White, S. (2014). Media social action campaigns: a theoretical approach. Media Psychology Review, 7(1). Retrieved from http://mprcenter.org/review/media-social-action-campaigns-a-theoretical-approach/

Zeng, X., Sun, Q., Huo, B., Wan, H., \& Jing, C. (2010). Integrated solid waste management under global warming. The Open Waste Management Journal, 3, 13-17. http://dx.doi.org/10.2174/1876400201003010013 
Krisnawati, Y., Susilowati, Irawati Al Muhdhar, M. H., Rochman, F., \& Budiasih, E. 